\title{
REFORMULATING STRATEGIES TO DEVELOP DEMOCRATIZATION THROUGH CIVIC EDUCATION IN ACEH
}

\author{
Anton Widyanto \\ Ar-Raniniry State Islamic University (UIN) Banda Aceh \\ Email: anton.widyanto@ar-raniry.ac.id
}

\begin{abstract}
This paper aims to pursue appropriate strategies to shape students' characters and sense of nationalism through formal education in Aceh. Grounded in the structured interviews, focused group discussions, and observations, this qualitative case study reveals that Aceh, as one province in Indonesia, which was trapped in prolonged army conflict, needs character education that focuses on the nation-state paradigm. The contemporary Acehnese society is also facing new cultural, ethnic, inter-religious conflicts, as well as internal conflicts among Muslims. The seed of these conflicts becomes increasingly worse when infiltrated by the contemporary political interests in the province. During the era of military conflict, Pendidikan Moral Pancasila (Pancasila Moral Education) was deemed "a dangerous" subject to be taught in Aceh schools due to its contradictory nature against the ideology of Gerakan Aceh Merdeka (Free Aceh Movement). Despite downgrading the students' spirit of nationalism, such situation has gradually been changed since a peace agreement between the two parties, Indonesian government and Gerakan Aceh Merdeka, was achieved in August 2005. Nevertheless, this demonstrates the need to overhaul curriculum and instructional strategies in the pursuit of the democratization in the province.
\end{abstract}

Keywords: Civic education, democratization, madrasah, teacher, Aceh

DOI: http:/ / dx.doi.org/10.20414/ ujis.v21i1.1179

\section{Introduction}

AS ONE of the provinces in Indonesia, the history of Aceh is full of heroism during which it played an important role in fighting against colonization in Indonesia. With the spirit of jïbäd, 
Acehnese people fought to be free from Portuguese, Dutch, and Japanese colonization. Even after Indonesian independence, Aceh continued to experience bloody war. Aceh is one of the several provinces in Indonesia that was trapped in prolonged armed conflict against the Central Government of Indonesia (Jakarta) for about 30 years. Thousands of people were killed either by Darul Islam, GAM (the Free Aceh Movement), or Indonesian army.

Interestingly, although Aceh has much diversity among ethnic groups and cultures in its population, ${ }^{1}$ there is no armed conflict among them. The internal conflict occurred during armed conflict between some Acehnese and non-Acehnese people (mostly Javanese). Many Javanese (mostly who followed transmigration program during the New Order) were expelled from Aceh. However, there remain stereotypes and prejudices among the various Acehnese groups. Furthermore, after the peace agreement, there has been a significant tension between them. Some districts want to be free from the currently recognized Aceh Province by creating another province. ${ }^{2}$ This is

${ }^{1}$ Aceh Province consists of nine tribes i.e Aceh, Tamiang, Alas (South East Aceh), Aneuk Jamee (South Aceh), Naeuk Laot, Simeulu dan Sinabang. Each of these tribes has its own language, and culture. "Sosial Budaya Provinsi Nanggroe Aceh Darussalam," n.d., accessed May 12, 2013, http:/ / www.indonesia.go.id/in/pemerintah-daerah/provinsi-nanggroeaceh-darussalam/sosial-budaya; "Seni dan Budaya Aceh," n.d., accessed May 12, 2013, http://2012.acehinvestment.com/Seni-dan-Budaya-Aceh.html.

2"Provinsi ALA dan Abas Dideklarasikan 4 November," n.d., accessed February 12, 2005, http://news.detik.com/read/2005/12/02/115550/ 490897/10/provinsi-ala-dan-abas-dideklarasikan-4-november?nd771108bcj; "Provinsi ALA-ABAS Sudah Final," n.d., accessed February 24, 2008, http:/ / www.waspada.co.id /index.php?option $=$ com_content\&view $=$ article \&id=12318:provinsi-ala-abas-sudah-final\&catid =14: medan\&Itemid = 27;

"Tunggu Proposal Pembentukan Provinsi ALA dan ABAS," n.d., accessed January 3, 2013, http://www.jpnn.com/read/2013/01/03/152814/ Tunggu-Proposal-Pembentukan-Provinsi-ALA-dan-ABAS; "Pasang Surut Perjuangan ALA ABAS di Aceh," n.d., accessed November 3, 2013, http:/ / atjehpost.com/read/2013/03/11/43381/0/39/Pasang-surut-perjuangan-ALA-ABAS-di-Aceh; "DPR ALA: Pemekaran tak Perlu Rekomendasi," n.d., accessed April 13, 2013, http:/ / aceh.tribunnew s.com/ 2013/04/13/dpr-ala-pemekaran-tak-perlu-rekomendasi. 
because they feel that they have been treated "unfairly" by the Acehnese Government in terms of regional development. Cultural differences also put some fire on this tension.

Moreover, one of the crucial constraints faced by the Acehnese Government nowadays concerns with the integration of the Acehnese people into one nation, the Republic of Indonesia. Although the peace agreement between GAM and the Republic of Indonesia was signed on August 15, 2005, some people (particularly the combatants of GAM) still feel that it only benefits some. Furthermore, some problems regarding the implementation of Act No. 11/2006 as a result of the peace agreement also make the integration a challenge in the province. $^{3}$ Consequently, the democratization process in the region also still needs to be promoted.

Many scholars have found that democratization is still a problem, particularly for youth. Some studies show the decline of youth's political participation and democracy. Thus, establishing positive civic education for young people is a catalyst for building democracy. ${ }^{4}$ To do this, schools play an

${ }^{3}$ The debate on the implementation of the Act No. 11/2006 on Aceh Government always be important issue in every governor election in Aceh. In 2017, this issue has been raised again by most governor candidates. A hot debate on the result of the election also makes some tensions. "UUPA Dipakai Saat Terdesak," n.d., accessed March 19, 2017, http:/ / aceh.tribunnew s.com/2017/03/19/uupa-dipakai-saat-terdesak;

"Politisi PA Tak Berani Mundur," n.d., accessed March 19, 2017, http:/ / aceh.tribunnews.com/2017/03/19/politisi-pa-tak-berani-mundur.

"Beth C. Rubin, "There's Still Not Justice': Youth Civic Identity Development Amid Distinct School and Community Contexts," The College Record 109 (February 2007): 449-481; Lauren Fieldman, "Identifying Best Practices in Civic Education: Lessons from the Student Voices Program," American Journal of Education (November 2007); David S. Crystal and Matthew DeBell's, "Sources of Civic Orientation among American Youth: Trust, Religious Valuation, and Attributions of Responsibility," Political Psychology 23 (March 2002): 113-132; Joseph Kahne, Bernadette Chi, and Ellen Middaugh, "Building Social Capital for Civic and Political Engagement: The Potential of High-School Civics Courses," Canadian Journal of Education 29 (2006): 387-409. 
important role in this regard due to the provision of a strong relationship between democratization and school. ${ }^{5}$

With respect to the democratization process through education in Indonesia, it cannot be separated from the discussion of civic education. During Soeharto's era (the second president of the Republic of Indonesia), also known as the New Order regime, civic education was called Pendidikan Pancasila. Pancasila is a philosophical concept formulated by the first president of the Republic of Indonesia, Soekarno, to unite Indonesian people who are diverse in terms of religions, ethnic groups, languages, and cultures. It consists of five principles, namely, belief in the one true God, just and civilized humanity, the unity of Indonesia, democracy guided by the wisdom of representative deliberation, and social justice for all Indonesians.

During the New Order (Orde Baru), Pendidikan Pancasila was used as a political tool to empower Soeharto's political position in Indonesia. From the 1970s to the 1990s, it was called Pancasila Moral Education (Pendidikan Moral Pancasila). Then, based on the 1994 curriculum, it was changed into Pancasila, and Citizenship Education in 2004. ${ }^{6}$ It is a compulsory subject from elementary school to higher education. Moreover, Javanization (the accommodation of only Javanese culture), rather than the inclusion of other Indonesian cultures, dominates the subject contents. This condition made those not of Javanese descent upset. Hence, teaching civic and moral education became a sensitive subject in the provinces that undergo a political conflict with the government of Indonesia, like Aceh.

5oel Westheimer and Joseph Kahne, "What Kind of Citizen? The Politics of Educating for Democracy," American Educational Research Journal 41 (2004): 237-269.

6U. S. Winataputra, "Pendidikan Kewarganegaraan untuk Perguruan Tinggi: Suatu Kerangka Acuan [Civic education for higher education: A frame of reference]" (presented at the Seminar Nasional III Pendidikan Kewargaan (Civic Education) di Perguruan Tinggi [Third National Seminar on Civic Education in Higher Education], Jakarta, Indonesia, October 2003), 2; Eka Srimulyani and Sa'eda Buang, "Pendidikan Islami (Islamic Education): Reformulating A New Curriculum for Muslim Schools in Aceh, Indonesia," in Muslim Education in the 21st Century: Asian Perspectives, ed. Sa'eda Buang and Phyllis Ghim-Lian Chew (London: Routledge, 2014), 90-108. 
Speaking about civic and moral education, Munawar ${ }^{7}$ who works for the institution of education quality assurance in Aceh told me that during the armed conflict, it was very dangerous to teach civic education in schools. This subject contains the issue of nationalism and patriotism which relate to Javanization. Since the Free Aceh Movement had a vital agenda to free the Acehnese from Indonesia; such lessons were prohibited at schools in rural areas. Furthermore, in the time of armed conflict in Aceh, the safety of teachers particularly in remote areas could not be guaranteed. Many schools were burnt down because they were regarded as the propaganda of the Government of Indonesia. Many teachers were asked to support the Free Aceh Movement by paying pajak nanggroe (payments levied by the Free Aceh Movement).

For this reason, this study explores this tension and how the Acehnese Government tries to figure out the issue through civic education. How is civic education taught in Senior High Schools in Aceh? What are problems faced by the teachers in teaching civic education in Aceh and how they solve them? What should the teachers do pertaining to the teaching of civic education to promote democratization in Aceh?

This study employs a qualitative case study design in which the empirical data are collected through semi-structured interviews, focus group discussions, and observations. The empirical data are qualitatively analyzed during and after the data collection. In this section, I describe the settings of study, including the subjects, the interviews and observation process, the data analysis process, and findings.

This study took place in four Madrasah (State Islamic Senior High Schools): MAN 2 and MAN Rukoh, and MAN 2 Peusangan and Sukma Senior High School respectively located in Banda Aceh and Bireuen. The reasons for choosing the two cities are because the former is the capital province of Aceh, which represents the development of Aceh during armed conflict between Free Aceh Movement and Indonesian Army (1976-2005), and after the peace agreement (2005-present),

7Interview with Munawar (pseudonym), March 15, 2016. 
while Bireuen is one of the several districts in Aceh that undergoes the prolonged armed conflict.

The purposive sampling technique was used in this study. The participants were the school principals, civic education teachers, and students chosen purposively drawing on the aims of the study and two criteria, namely, profession and competency. In addition, to gain more complex date for validity assurance, I also chose some experts on civic education, including the experts from Ar-Raniry State Islamic University and the Institution for Education Quality Assurance Banda Aceh.

\section{Data Collection}

Multiple data collection methods were employed including interview, focus group discussion, and observation. Semistructured interview techniques were used to garner the data from five civic education teachers i.e Zainuddin, Fatimah, Azizah, Murni, and Mila; 8 four principals i.e. Syakur, Marwan, Sairuman, and Ilham; ${ }^{9}$ two experts from State Institute for Islamic Studies (IAIN) Ar-Raniry i.e. Bustamam and Jauhar, ${ }^{10}$ and one from the Institution for Education Quality Assurance Banda Aceh, Munawar. ${ }^{11}$ The focus group discussions were conducted for non-civic education teachers and students from those schools. There were two focus group discussions in each district. All the interviews and focus group discussions were recorded and transcribed. I also took field notes to highlight and record some important points.

Another data collection method employed was observations. I observed four classes of civic education in Banda Aceh and Bireuen to look into the teaching-learning process of civic education, the teaching strategies employed by teachers, interactions between teachers and students, students' attitudes, learning facilities and decorations. All of these observations were documented by using field notes.

${ }^{8}$ These names are pseudonyms.

${ }^{9}$ These names are pseudonyms.

10These names are pseudonyms.

${ }^{11}$ This name is pseudonym. 
To analyze the data using content analysis, I coded the data gained through interviews and observations. There were five codes for interviews including civics curriculum, local curriculum, teaching method and strategies, constraints, student's responses, and democratization. Meanwhile, for field notes, there were also five codes including class facilities, teaching method, student's responses, reading activities, and service learning. Moreover, to enrich these data, I also wrote memos for interviews and observations.

After the coding process, I drew two visual displays for interviews and observations. These visual displays helped me in synthesizing the data. Subsequently, I analyzed the data using action theory. ${ }^{12}$ This theory consisted of two domains: explicit (espoused theory) and implicit (theory in use).

In present study, I use the espoused theory to understand the policy to implement civic education curriculum in Senior High Schools in Aceh, while the theory in use was used to understand why this program was important. Moreover, through the theory of action, I analyze the findings of this study not only from actors (teachers) but also from situations and varieties of orientations of actors to situations. The theory of action is used to analyze teachers' and principals' perspectives on civic education curriculum implemented in Aceh during and after armed conflict, and how class situation was during civic education learning. Furthermore, this theory was also used to search the appropriate teaching strategies for civic education.

\section{The Historical Background of Aceh}

Geographically, Aceh is located in a very strategic place. It is surrounded by Malacca Strait to the north and east. Hence, in the sixteenth and seventeenth century, Aceh played a central role in the international trade. The Malacca Strait connects several areas and cultures including India and China. ${ }^{13}$

${ }^{12}$ C. Argyris and D. Scho" n, Theory in Practice: Increasing Professional Effectiveness (Jossey-Bass, San Francisco, 1974), 6.

13Zakaria Ahmad, Sekitar Keradjaan Atjeh dalam tabun 1520-1675 (About Acehnese kingdoms 1520-1675) (Medan: Monora, 1972); D. H. Burger and Prayudi, Sejarah Economic-Sosiologis Indonesia (The socio-economical history of 
Before Islam came to Aceh, some Acehnese people followed pagan religions, others were Hindu or Buddhists. There were many small Hindu kingdoms established like Indrapuri, Indrapatra, Kroeng Raya, Pasei, and Jeumpa (Peusangan). ${ }^{14}$ All of these small kingdoms continually fought to expand their rule. Finally, after Islam came to Aceh and attracted many people because of its teachings that promote equality and the denial of castes, the influence of Hinduism and Buddhism came to an end and was replaced by Islam.

There are three theories explaining how Islam came to Aceh. The first theory says that Islam came to Aceh directly from Arabia; the second theory says that it came from India, and another says that it came from China. Then, based on the conference of the history of Islam in Indonesia which was conducted in Medan on March 17-20, 1963 and the conference of Islamic history in Aceh on July 16, 1978, it was concluded that first, Islam penetrated Indonesia in the first century of Islamic calendar (hijr) or around seventh and eighth century A.D directly from Arabia; second, the first region where Islam came into Indonesia was Aceh and the early Islamic kingdoms in Aceh are Perlak, Lamuri, and Pasai; third, Islam was preached peacefully. ${ }^{15}$

According to its history, the Kingdom of Aceh was founded in the early sixteenth century. It was regarded as a powerful kingdom at that time. Under Sultan Iskandar Muda, in the early seventeenth century, the kingdom gained its golden age. He made Aceh as one of the most important military and trading powers in the region. Moreover, it maintained relations with foreign power, including the Ottoman Empire, France, and

Indonesia) (Jakarta: Pradnyamitra, 1962); Anthony Reid, Witnesses to Sumatra: A Travelers Anthology (New York: Oxford University Press, 1995); R. Michael Feener, Sharia and Social Engineering: The Implementation of Islamic Law in Aceh, Indonesia (Oxford: Oxford University Press, 2013).

${ }^{14}$ Ismail Jacoeb, Atjeh, 1946, 11.

15"Risalah Sejarah Masuknya Islam di Indonesia" (The Symposium on the History of Islamic Entrance to Indonesia, 1963); "Risalah Sejarah Masuk dan Berkembangnya Islam di Daerah Istimewa Aceh" (The symposium on the History of Islamic Entrance and Development in the Special Region Aceh, 1978). 
Great Britain. When the Dutch appended Aceh in 1874, the Acehnese started a guerilla war that continued until 1912.

The armed conflict in Aceh after the independence of Indonesia in 1945 can be divided into two phases. The first phase of the conflict began in 1953 when Indonesia experienced Darul Islam. These rebels wanted to make Indonesia become an Islamic state. They were not only in Aceh but also in several other provinces in Indonesia including West Java and Sulawesi. ${ }^{16}$ In Aceh's case, the rise of Darul Islam was because of two specific reasons: first, the use of Pancasila philosophy as the philosophical foundation of the Indonesia state rather than Islamic sharia' (Islamic law); second, the fusion of Aceh into North Sumatera in 1950. Eventually, this rebellion failed to achieve its goals. Through various approaches including military operations and negotiations, this rebellion was annihilated.

In 1976, the second phase of the conflict began. In this year, Hasan Tiro formed the Free Aceh Movement (GAM), and declared the independence of Aceh. Here, the relationship between the central government of the Republic of Indonesia and Aceh local government during the military conflict was maintained. Nevertheless, this relationship could not run normally because of military troubles coming from the GAM. Ironically, the Republic of Indonesia's response to such separatist tensions in Aceh and other provinces in defense of its conception of an organic, unitary state has emphasized military repression and civic education through a highly centralized educational bureaucracy. ${ }^{17}$ During President Soeharto (the new order), Habibie (the reformation order), Abdurrahman Wahid, and Megawati Soekarnoputri, the approaches were still focused

${ }^{16}$ Nazaruddin Sjamsuddin, The Republican Revolt: A Study of the Acebnese Rebellion (Singapore: Institute of Southeast Asian Studies, 1985); C. van Dijk, Rebellion Under the Banner of Islam: The Darul Islam in Indonesia (The Hague: Martinus Nijhoff, 1981).

${ }^{17} \mathrm{D}$. Kingsbury and H. Aveling, Autonomy and Disintegration in Indonesia (New York: RoutledgeCurzon, 2003); J. Bertrand, Nationalism and Ethnic Conflict in Indonesia (Cambridge: Cambridge University Press, 2004); F. Kalidjernih, "Post-Colonial Citizenship Education: A Critical Study of the Production and Reproduction of the Indonesian Civic Ideal" (Ph.D. Dissertation, University of Tasmania, 2005). 
on military operations. In fact, these approaches were not effective to stop the Free Aceh Movement's actions. Moreover, the military operations made the rebellions become more popular in Acehnese society. ${ }^{18}$ For most Acehnese people, it was a symbol of struggle, because the military operations made many human rights violations, such as torture, kidnapping, and rape.

Although there were several efforts to solve this conflict such as Cessation of Hostilities Agreement (CoHA) between the Indonesian government and the Free Aceh Movement (GAM), the conflict still continued. ${ }^{19}$ This 30 year period of conflict not only affected the economy but also influenced the education sector as well. As part of this conflict, many schools were burned and many teachers fled from this province.

However, on 26 December 2004, a big earthquake and tsunami struck the Indian Ocean. Aceh felt the impact of this natural disaster as well. It killed about 132,000 people with 37,000 missing and also destroyed hundreds of buildings including schools.

This giant disaster impacted the conflict between the warring factions as well. It forced the Free Aceh Movement (GAM) and the Indonesian Government to sit together and discuss another peace agreement in Helsinki. Unlike the previous agreements, this new Memorandum of Understanding was more successful. It is because of the commitment of both sides to end the conflict became stronger after the tsunami destroying the region. Besides, the implementation of the agreement was overseen by international organizations. Therefore, both Indonesian Government and Aceh Free Movement tried to maintain peace, because no one wanted their image destroyed in front of international organizations.

Although there was still tension during post-conflict phase, it was not bitter. The integration of Free Aceh Movement combatants to Acehnese society was problematic because many people still doubted whether the peace agreement would endure. Nonetheless, after Act No. 11/2006 on Aceh government as a

${ }^{18} \mathrm{ICG}$ Asia Report $\mathrm{N}^{\circ} 17$, “Aceh: Why Military Force Won’t Bring Lasting Peace," June 12, 2001.

19CG Asia Report, "Indonesia Briefing," May 9, 2013. 
product of peace agreement in Helsinki was implemented by the Government of the Republic of Indonesia, many people become more optimistic. As a result, the regional election for governor and heads of district ran successfully, although there were some tensions particularly in the recent election 2017.

\section{Civic Education Curriculum}

The design of civic education curriculum is centralized in Jakarta. Hence, there is little opportunity for local teachers to accommodate local culture and history. Most teachers I interviewed said that there were changes several times in civic education curriculum from PMP (Pendidikan Moral Pancasila/ Pancasila Moral Education) to PPKN (Pendidikan Pancasila dan Kewarganegaraan/Pancasila and Citizenship Education), and to PKN (Pendidikan Kewarganegaraan/Citizenship Education). If PMP emphasized the moral aspect of citizenship based on the Pancasila values, and PPKN has additional aspects of citizenship, PKN is more focused on the rights and responsibilities of citizens. This change can be traced from the national curriculum in 1994, curriculum based competency, and 2006 curriculum. The change in the curriculum was influenced by the change of political conditions in Indonesia particularly when Indonesia shifted from a "military government" (the New Order era) to a "civil society government" (Reformation Era).

According to most of the civic education teachers I interviewed, students are less interested in learning about civic education because it is not part of the national examination for class 12. Moreover, the lack of accommodation of local culture and history also makes this subject less interesting for them. However, teachers usually include some issues on Acehnese' culture and history when they teach particular materials like the rights and responsibilities of citizens. The issues normally also come up in class discussions. Interestingly, regarding the past armed conflict issues in Aceh, some teachers argued that it should not be included in civic education materials. If the issue came up in the discussion, teachers shifted to a discussion of another issue. Teachers did not want students to remember the past conflict and want them to face the future of Aceh in a 
positive way. They were afraid of an emerging spirit to fight for Aceh freedom like in the past. Fatimah said, "Most of our students are victims of the past armed conflict in Aceh, and if we discuss the past problems, their spirit to rebel will grow up. So, I think, issues of the past armed conflict should not be taught in class". ${ }^{20}$

However, some teachers said that teaching about the past armed conflict is important. It will give them insights to analyze results of armed conflict. Civic education teachers should teach the consequences of armed conflict, not about who wins or loses. Moreover, students should know how to resolve conflicts. Thus, conflict resolution is something very important here. By learning conflict resolution, it will prevent students from repeating the past. Mila said

"We try to motivate students not to be afraid to mention Gerakan Aceh Merdeka (GAM). I think it is no problem to do that in class although we are surrounded by GAM members. We used to discuss conflict problems and their consequences. Furthermore, we also show pictures or movies we got from NGOs to explain the negative effects of the past armed conflict in Aceh; the position of GAM and TNI. We do not discuss who is right and wrong. We show the impacts of armed conflict and discuss why it happened in Aceh. We try as far as we can. We try to be neutral in this case, but we still have to teach them". ${ }^{21}$

Still concerning the idea to include local culture and local history in civic education such as the history of armed conflict in Aceh, MoU Helsinki, or special autonomous provisions for Aceh, many participants of this study informed me that they never got any suggestion about it from their parents. Although there are meetings that include parents as a school committee, usually the problems discussed are related to school financials, school plans, or information about some regulations. Many parents give the responsibility to educate children to schools. Mila continued to say,

"Parents generally only focus on sending their children to schools. So, if the question specifically asks whether parents have ever suggested the inclusion of some materials in particular subjects, the answer is never. Usually, they are busy parents. Even, some of them say that it is up to

20Interview with Fatimah (pseudonym), March 18, 2016.

${ }^{21}$ Interview with Mila (pseudonym), March 14, 2016. 
the school to educate their children. They do not really care about what their children learn at school". ${ }^{22}$

\section{Civic Education during and after Armed Conflict}

As previously discussed, Aceh is one province in Indonesia that endured armed conflict. During the conflict between GAM and Indonesian National Army (TNI), most participants explained that civic education was a "dangerous" subject to teach in schools in Aceh. It is because this subject teaches students to be good citizens in Indonesian frame. In other words, it sends the message not to rebel Indonesia. This message was perceived to be opposite of their mission to free Aceh. Hence, since there were senior high school students who were GAM followers, teaching this subject became dangerous. Basically, not only civic education that was negatively perceived by some students, but also other subjects identical to the Indonesian ideology like Bahasa Indonesia, and the Constitution. Syakur, told me that before becoming a principal of MAN 2 Banda Aceh, he taught the subject in MTsN (State Islamic Junior High School). He said that almost no one was brave enough to teach the subject. Hence as a new teacher who just moved from another junior high school in East Aceh because of armed conflict, he was offered by the principal to teach civic education. As a homeroom teacher of class 10, he accepted the offer. He felt it was not easy to teach the subject because many of his students who were followers of GAM rejected it. They said that the subject has no significance at all to teach because they want to be free from Indonesia. He said:

"....at first students rejected (civic education). Some of them said, "Why should we study civic education when we will be free from Indonesia and will have an independent state?" In brief, they could not accept civic education. In fact, not only civic education or constitution that they rejected but also other subjects like Bahasa Indonesia. They protested and have no will to study Bahasa Indonesia. According to them, they should learn Bahasa Aceh because it will be a national language if they split up from Indonesia. That was what they thought at that time. However, with all efforts, through various methods, I tried

22Interview with Mila (pseudonym), March 14, 2016. 
to persuade them that civic education and constitution are important subjects to learn". 23

To solve the problem, Syakur offered them a discussion and debate about the concept of state. He asked the students several questions about the requirements to build an independent state. Since they were only sympathizers of GAM ideology and have little understanding of concept of the state, they did not know how to answer those questions. Then, he emphasized the importance of civic education and constitution subjects to learn at schools. He explained that it would be useful for those who were GAM followers and sympathizers since they wanted to free Aceh from Indonesia and build an independent state. Without mastering the knowledge about the concept of the state, they would have significant problems if they were to gain their freedom. After understanding the importance of the subject, they finally could accept civic education. He said:

"Interestingly, what I remember, one time I asked them to discuss with me in class. I asked them, "Ok, I do agree that you want to build an independent state. As your civic education teacher, I agree on that. However, my question is what do you know about the requirements to build an independent state? At that time, they could not answer the question. That makes sense because they only get some "doctrines" about Aceh's independence from their friends or others. When they could not answer my question, I told them that civic education and constitution that we learn now is very important. By learning this subject, you will be clever. If you are clever, you can build an independent nation because you already knew the concept of state. For instance, you would know the system of the Republic of Indonesia, the United States, or other states in Europe. You also would know their concepts, systems, regulations, etc. Hence we will know much and can conclude what state we should make for Aceh in the future. Since that, they could accept civic education to be taught in the school". ${ }^{24}$

A similar experience was also explained by Fatimah and Azizah. Fatimah is a civic education teacher at MAN Rukoh Banda Aceh who has been working for 11 years, while Azizah is a civic education teacher at SMA 2 Peusangan, Bireuen, who has been working for 15 years. Fatimah and Azizah told me that

23Interview with Syakur (pseudonym), March 10, 2016.

24Interview with Syakur (pseudonym), March 10, 2016. 
they felt a long hard period in teaching civic education in their schools. Like Syakur, during armed conflict, some of their students also rejected the subject. More than that, Azizah was even threatened to be killed by her students who were GAM followers. The problem was not only related to the subject she taught but also because her husband was not Acehnese.

Fatimah said,

"Usually our students who were followers of GAM have little knowledge and were influenced by their environment. They hated me because I teach civic education. Nevertheless, I told them that this subject is like a bridge for them. If you do not like it, that is your right. Above all, you have to know about it. Wherever we are, we have to know how to live as a citizen. So, if you do not like, once again, that is your right. I just hope that you can answer questions presented in the examination. After the exam, either you can use it or throw it away". ${ }^{25}$

To solve the problem Fatimah explained,

"Normally, I called students who hated me and made verbal abuses, then, I began to ask what they want. My heart was hurt by their attitudes, but I was not angry at them. I asked them to express their feelings. By doing so, usually, they can understand my position". ${ }^{26}$

Similarly, Azizah also used the method of discussion to solve rejection of her students on civic education. She said that sometimes she was afraid of students who threatened her life. However, she tried to cope with that by her belief in God. She submitted to God's fate for every problem she faced. ${ }^{27}$

After the peace agreement between GAM and the Republic of Indonesia was signed on August 15, 2005, civic education gradually became acceptable. It does not mean that this subject became a "favorite" one, but this subject has no risk to teach at senior high schools in Aceh anymore. This condition cannot be separated from the peaceful situation after the prolonged armed conflict as a fruit of the MoU Helsinki followed up by the Act No. 11/2006 on Aceh Government.

When I asked whether the materials in civic education are still relevant for Aceh people, most civic education teachers said

\footnotetext{
25Interview with Fatimah (pseudonym), March 18, 2016.

26Interview with Fatimah (pseudonym), March 18, 2016.

27Interview with Mila (pseudonym), March 14, 2016.
} 
it is still relevant. Fatimah said, "I think they are still relevant because during armed conflict, students were influenced by the conditions outside the school, while now such influences do not exist". Regarding this matter, Syakur explained, "I think civic education is still relevant to teach in Aceh because we have to know our government system. If we do not teach civic education, perhaps students do not know what parliament is, or what kind of system we use in our politics in Indonesia. These topics are covered in civic education materials. Hence, once again, civic education is still relevant for Aceh people nowadays". ${ }^{28}$

\section{Teaching Strategy}

Most participants of this study said that they often use lecturing as a method to teach civic education. However, for some materials, they also use other methods such as discussion, and role play. Azizah explained, "Mostly, I use lecturing in teaching civic education, and sometimes I use discussion. I think other methods are not suitable to use in this school, like learning outside of class. I even use it, but students are not seriously involved". ${ }^{29}$ Moreover, Fatimah told me, "There are some materials that are not suitable to teach by using a particular method, for example, materials on law. Regarding law materials, I often ask my students to role play in which they can practice like in a real court". 30

From my observation, I saw that students did not really care about materials taught. Some of them were talking each other, especially who sat in the back row. Some students who really paid attention to the lecturing of teachers usually were girls. They usually like to sit in the front row. Regarding this problem, Azizah said, "Usually students are interested in learning civic education when we connect the materials with the facts that we face every day (authentic). So, whatever the materials are, if we relate them to our surrounding, they will be interested in learning. If we only focus on what is written in the handbook,

28Interview with Syakur (pseudonym), March 10, 2016.

29Interview with Azizah (pseudonym), March 16, 2016.

30Interview with Fatimah (pseudonym), March 18, 2016. 
normally they are not interested. Hence, it really depends on the teacher's innovation". 31

What Azizah said above is in line with what students told me in focus group discussion. When I asked them about their impression to study civic education, the answers were different. Some students said they lacked the enthusiasm to study materials that needed memorization like the Acts or constitution. However, they were interested in learning some topics related to the daily problems like corruption, collusion, or human rights. This is because they often watch those problems on TV, or they read about them in the newspaper, or on the internet.

The aforementioned findings show that teaching and learning civic education in Aceh still, has many problems. The problems can be classified into three parts: problems pertinent to curriculum, teaching strategy, and democratization.

Concerning the problems related to civic education curriculum, I think it is really important to accommodate local cultures and history of Aceh. Based on the interviews and focus group discussion, most civic education teachers and principals hope that civic education includes those materials. However, since civic education curriculum is designed in Jakarta, what civic education teachers need to do is to modify the materials by connecting to local culture and history.

This improvement is really possible because according to the Act No. 11/2006 on Aceh Government Chapter 215 Number 1, "Education in Aceh is a part of a national education system that is adjusted to the characteristic, potentiality, and need of society". Then, the local regulation (Qamün) No. 5/2008, Chapter 3 says, "Aceh is a province that constitutes of lawful society that has specialties and particular authorities to manage and regulate government affairs and the interest of local people in line with regulations in the system of the Republic of Indonesia based on the Constitution of the Republic of Indonesia 1945, which is led by a governor". Moreover, these special autonomy is strengthened by the regulations on the

31Interview with Azizah (pseudonym), March 16, 2016. 
division of education management authorities. Chapter 5 of this Qamūn says, "The Government of Aceh and District Governments implement the specialty of Aceh in education altogether and add local materials which are in line with Islamic Shari'a". Then, regarding curriculum, chapter 35 No. 4 says, "School or madrasah curriculum of all kinds and levels can add local curriculum based on local needs". This regulation indicates clearly that Aceh has rights to make innovation in education by including local curriculum. Several issues like special autonomous provisions, the system of local government such as Wali Nanggroe (provincial head of Acehnese culture, custom, and tradition), Tuba Peut (four important leadership elements in a sub-district), Tuba lapan (eight important leadership elements), or history of conflict in Aceh that stresses conflict resolution can be included either in local curriculum or in the materials of civic education.

Next, regarding problems with teaching strategy, I think civic education teachers need to be trained in order to upgrade their capacity. Since civic education is not a subject tested in the national examination, training for teachers is rarely organized. Moreover, meetings of subject teachers in Musyawarah Guru Mata Pelajaran (MGMP/ Coordination Forum for Subject Teachers) are also not actively conducted. Training for teachers can be focused on how to make civic education more interesting for students. The use of lecturing as a principal method without combination with other methods will make this subject boring for them. I think various methods related to collaborative learning and learning by doing such as discussion, service learning, field trips, and guest speakers can help teachers to make civic education interesting.

Regarding the field trips students can learn about the judicial branch and the court systems. Then, they can make a mock trial at the school where the students play parts and read the roles of different people. Then, they can begin work on a more in-depth mock trial where the students will become the attorneys, the witnesses, and defendants. They can make up their own questions. Teachers then can travel with students to the Court House where they can view an actual trial. The students will 
learn how the judge works, what goes on in the courtroom, courtroom etiquette, all of the players, and key components in the courtroom. This, of course, will be very useful for them to understand the judicial system in their country.

Furthermore, concerning service learning, teachers can make a project assignment for students to do in society. They can choose what and where they will conduct service learning. They can choose for example orphanage residence, mosque, foundation, etc. With this regard, they can experience and learn directly how to live in different situations which will be very useful for their future lives.

Furthermore, regarding problems of democratization, according to the Act No. 11/2006, Chapter 216 Number 1, "Every Acehnese has right to have qualified education with Islamic values in line with the development of knowledge and technology"; Number 2, "Education which is indicated in the number 1 must be done on democratic basis and justice along with respecting human rights, Islamic values, culture, and diversity in the nation". This law clearly sends a message that democracy is an important basis to build Aceh. However, it is also crucial to note that democracy in Aceh must respect human rights, Islamic values, culture, and diversity in Indonesia.

For this reason, I think what students need to learn from civic education is how to be good citizens. Instead of memorizing chapters of law, or Pancasila, it will be more useful if students can understand how to be "citizens in a democracy, what role citizen play in a democracy, and how to fully and effectively meet their obligations to fulfill those roles". ${ }^{32}$ To implement this concept, I think civic education teachers can ask students to make a mock general election to educate them that one of their responsibilities is to elect their leaders. Moreover, teachers also can ask students to do a site visit to watch directly how their representatives in Dewan Perwakilan Rakyat Aceh (Regional People Representatives of Aceh Province) and Dewan

32Susie Burroughs et al., "Teaching for and about Citizenship in a Democratic Society: Comparative Views of a Selected Civic Educators in the United States, Europe, and Latin America," International Journal of Social Education 22, no. 2 (2008): 49-69. 
Perwakilan Rakyat Kabupaten (Regional People Representatives at District level) doing their responsibilities. In line with this, in a more concrete way, students also can learn directly from student body at schools. All of these methods are used because civic education should not only be taught "in book", but "in action". This is what can be termed "applied civics".

\section{Conclusions}

Drawing on the aforementioned findings and description, it can be understood that civic education is imperative to be taught at schools in Aceh. The historical background of Aceh which is full of blood must be replaced by democratization for its citizens. Hence, education plays an important role here because through education students can learn how to be morally good citizens. Moreover, they can also learn how to maintain a peaceful condition in Aceh. The Memorandum of Helsinki which was signed on August 15, 2005, and followed up by the Act No. 11/2006 emphasizes that the contemporary and future Aceh must be developed under the frame of the Republic of Indonesia. As a consequence, to promote democratization towards character building in Aceh, civic education must be empowered through various ways. Regarding the curriculum, civic education in Aceh should include local issues including culture, special autonomous provisions, and Aceh history. The history of conflict in Aceh should be neutral and objective. It should focus on strengthening human rights, and the consequences of past conflict, without blaming. Then, concerning teaching strategy, civic education teachers in Aceh still need to be trained. The problems here are not only concerned with the exclusion of this subject from the national examination, but also the methods of teaching. Civic education can be an interesting subject for students to learn if the teachers can connect materials with a factual condition in society. Hence, the improvisation of the teachers in teaching this subject is really imperative. Next, regarding the democratization process in Aceh, students need to learn how to live in a democratic society. Therefore, it is important to teach them to be good citizens. It 
can be done by giving them opportunities to learn directly from their surrounding environments them.

Another aspect that needs to notice is concerning diversities in Aceh. These diversities include ethnic groups, languages, religions, and cultures. On the one hand, these diversities can be a positive power to develop an Acehnese society in the future. However, on the other hand, it also can bring harms to the future. To attain the positive outcome, it needs a strong commitment from the stakeholders to implement multicultural education in schools. One possible way to do it is by integrating multicultural education into civic education. I think with Indonesian curriculum of 2013 that allocates more dependency for teachers to make innovation in teaching-learning process, this alternative is applicable.

\section{References}

Ahmad, Zakaria. Sekitar Keradjaan Atjeh dalam tabun 1520-1675 (About Acebnese kingdoms 1520-1675). Medan: Monora, 1972. Argyris, C., and D. Scho" n. Theory in Practice: Increasing Professional Effectiveness. Jossey-Bass, San Francisco, 1974.

Asia Report, ICG. "Indonesia Briefing," May 9, 2013.

Asia Report N¹7, ICG. "Aceh: Why Military Force Won't Bring Lasting Peace," June 12, 2001.

Bertrand, J. Nationalism and Ethnic Conflict in Indonesia. Cambridge: Cambridge University Press, 2004.

Burger, D. H., and Prayudi. Sejarah Economic-Sosiologis Indonesia (The socio-economical history of Indonesia). Jakarta: Pradnyamitra, 1962.

Burroughs, Susie, Peggy F. Hopper, Kay Brocato, and Angela Sanders. "Teaching for and about Citizenship in a Democratic Society: Comparative Views of a Selected Civic Educators in the United States, Europe, and Latin America."

International Journal of Social Education 22, no. 2 (2008): 49-69.

Crystal, David S., and Matthew DeBell's. "Sources of Civic

Orientation among American Youth: Trust, Religious Valuation, and Attributions of Responsibility." Political Psychology 23 (March 2002): 113-132. 
van Dijk, C. Rebellion Under the Banner of Islam: The Darul Islam in Indonesia. The Hague: Martinus Nijhoff, 1981.

Feener, R. Michael. Sharia and Social Engineering: The Implementation of Islamic Law in Aceh, Indonesia. Oxford: Oxford University Press, 2013.

Fieldman, Lauren. "Identifying Best Practices in Civic Education: Lessons from the Student Voices Program." American Journal of Education (November 2007).

Ismail Jacoeb. Atjeh, 1946.

Kahne, Joseph, Bernadette Chi, and Ellen Middaugh. "Building Social Capital for Civic and Political Engagement: The Potential of High-School Civics Courses." Canadian Journal of Education 29 (2006): 387-409.

Kalidjernih, F. "Post-Colonial Citizenship Education: A Critical Study of the Production and Reproduction of the Indonesian Civic Ideal." Ph.D. Dissertation, University of Tasmania, 2005.

Kingsbury, D., and H. Aveling. Autonomy and Disintegration in Indonesia. New York: RoutledgeCurzon, 2003.

Reid, Anthony. Witnesses to Sumatra: A Travelers Anthology. New York: Oxford University Press, 1995.

Rubin, Beth C. “'There's Still Not Justice': Youth Civic Identity Development Amid Distinct School and Community Contexts." The College Record 109 (February 2007): 449-481.

Sjamsuddin, Nazaruddin. The Republican Revolt: A Study of the Acehnese Rebellion. Singapore: Institute of Southeast Asian Studies, 1985.

Srimulyani, Eka, and Sa'eda Buang. "Pendidikan Islami (Islamic Education): Reformulating A New Curriculum for Muslim Schools in Aceh, Indonesia." In Muslim Education in the $21^{\text {st }}$ Century: Asian Perspectives, edited by Sa'eda Buang and Phyllis Ghim-Lian Chew, 90-108. London: Routledge, 2014.

Westheimer, Joel, and Joseph Kahne. "What Kind of Citizen? The Politics of Educating for Democracy." American Educational Research Journal 41 (2004): 237-269.

Winataputra, U. S. "Pendidikan Kewarganegaraan untuk Perguruan Tinggi: Suatu Kerangka Acuan [Civic education for higher education: A frame of reference]" presented at 
the Seminar Nasional III Pendidikan Kewargaan (Civic Education) di Perguruan Tinggi [Third National Seminar on Civic Education in Higher Education], Jakarta, Indonesia, October 2003.

"DPR ALA: Pemekaran tak Perlu Rekomendasi," n.d. Accessed April 13, 2013. http://aceh.tribunnews.com/2013/04/13/ dpr-ala-pemekaran-tak-perlu-rekomendasi.

"Pasang Surut Perjuangan ALA ABAS di Aceh," n.d. Accessed November 3, 2013. http://atjehpost.com/read/2013/ 03/11/43381/0/39/Pasang-surut-perjuangan-ALA-ABASdi-Aceh.

"Politisi PA Tak Berani Mundur," n.d. Accessed March 19, 2017. http://aceh.tribunnews.com/2017/03/19/politisi-patak-berani-mundur.

"Provinsi ALA-ABAS Sudah Final," n.d. Accessed February 24, 2008. http://www.waspada.co.id/index.php?option=com_ content\&view $=$ article\&id $=12318$ :provinsi-ala-abas-sudahfinal\&catid $=14$ : medan\&Itemid $=27$.

"Provinsi ALA dan Abas Dideklarasikan 4 November," n.d. Accessed February 12, 2005. http://news.detik.com/read/ 2005/12/02/115550/490897/10/provinsi-ala-dan-abasdideklarasikan-4-november?nd771108bcj.

"Risalah Sejarah Masuk dan Berkembangnya Islam di Daerah Istimewa Aceh." The symposium on the History of Islamic Entrance and Development in the Special Region Aceh, 1978.

"Risalah Sejarah Masuknya Islam di Indonesia." The Symposium on the History of Islamic Entrance to Indonesia, 1963.

"Seni dan Budaya Aceh," n.d. Accessed May 12, 2013. http:/ /2012.acehinvestment.com/Seni-dan-BudayaAceh.html.

"Sosial Budaya Provinsi Nanggroe Aceh Darussalam," n.d. Accessed May 12, 2013. http://www.indonesia.go.id/in/ pemerintah-daerah/provinsi-nanggroe-aceh-darussalam/ sosial-budaya.

"Tunggu Proposal Pembentukan Provinsi ALA dan ABAS," n.d. Accessed January 3, 2013. http://www.jpnn.com/ 
$\mathrm{read} / 2013 / 01 / 03 / 152814 /$ Tunggu-Proposal-PembentukanProvinsi-ALA-dan-ABAS.

“UUPA Dipakai Saat Terdesak," n.d. Accessed March 19, 2017. http:/ / aceh.tribunnews.com/2017/03/19/uupa-dipakaisaat-terdesak. 